ELECTRONIC LETTER

\title{
Divergent phenotypes in Gaucher disease implicate the role of modifiers
}

\author{
O Goker-Alpan, K S Hruska, E Orvisky, P S Kishnani, B K Stubblefield, R Schiffmann, E Sidransky
}

J Med Genet 2005;42:e37 (http://www.jmedgenet.com/cgi/content/full/42/6/e37). doi: 10.1136/jmg.2004.028019

\begin{abstract}
Background: Gaucher disease is classified into neuronopathic and non-neuronopathic forms with wide phenotypic variation among patients sharing the same genotype. While homozygosity for the common L444P allele usually correlates with the neuronopathic forms, how a defined genotype leads to a phenotype remains unknown.

Methods: The genetic and epigenetic factors causing phenotypic differences were approached by a clinical association study in 32 children homozygous for the point mutation L444P. Direct sequencing and Southern blots were utilised to establish the genotype and exclude recombinant alleles. Glucocerebrosidase activity was measured in lymphoblast and fibroblast cell lines.

Results: Residual enzyme activity was highly variable and did not correlate with the observed clinical course. There was also a wide spectrum of phenotypes. Average age at diagnosis was 15 months, and slowed saccadic eye movements were the most prevalent finding. The most severe systemic complications and highest mortality occurred in splenectomised patients before the advent of enzyme replacement therapy (ERT). On ERT, as morbidity and mortality decreased, developmental and language deficits emerged as a major issue. Some trends related to ethnic background were observed.

Conclusion: The wide clinical spectrum observed in the L444P homozygotes implicates the contribution of genetic modifiers in defining the phenotype in Gaucher disease.
\end{abstract}

G aucher disease (MIM 230800, 230900, 2301000), the inherited deficiency of the lysosomal enzyme glucocerebrosidase (GBA; EC 3.2.1.45), results from an abnormal accumulation of the lipid substrate glucocerebroside. This multi-system disease presents with a vast spectrum of phenotypes, including a number of patients who defy categorisation into the classic three types, non-neuronopathic (type 1) and neuronopathic (types 2 and 3), yet represent a part of the phenotypic continuum. ${ }^{12}$ While it has been suggested that factors such as the environment or modifier genes contribute to the complicated phenotypes associated with Gaucher disease, the impact of these factors still remains elusive.

Chronic neuronopathic, or type 3, Gaucher disease commonly presents with diverse neurologic features at any time during infancy and early childhood. The most prevalent neurologic finding is a horizontal supranuclear palsy, often seen in association with severe systemic involvement. ${ }^{34}$ Other patients have mild systemic manifestations and moderate organomegaly, yet develop a slowly progressive neurological disease, with generalised seizures, myoclonus, ataxia, and/or dementia. ${ }^{5}$
The gene for human GBA is located on chromosome lq21. A pseudogene, located $16 \mathrm{~kb}$ downstream from the functional gene, shares $96 \%$ exonic sequence homology. ${ }^{6}$ The first described mutation in GBA, L444P, ${ }^{7}$ still remains the most frequently encountered disease-causing allele in neuronopathic patients, either as a single base substitution or as part of a recombinant allele. ${ }^{8}$ While it has been suggested that the genotype plays an important role in determining the degree of neurological involvement, ${ }^{9}$ the mechanisms by which a defined genotype leads to a particular phenotype remain unknown. Although homozygosity for the mutation L444P is considered to be predictive of neuronopathic disease, in a large Gaucher disease registry, 25\% of the patients identified with the genotype L444P/L444P were categorised as type $1 .{ }^{10}$ Moreover, earlier studies, conducted when genotyping relied solely on PCR methodologies, inadvertently may have included patients with recombinant alleles, thereby complicating the interpretation of the clinical spectrum associated with the point mutation L444P.

Several strategies, including the use of discordant sib pairs ${ }^{11}$ and mouse models, ${ }^{12}$ have been employed to determine the cause of phenotypic differences at a given disease locus. A genotypically homogeneous group also can provide valuable insights into the genetic and epigenetic factors that play a role in a single gene disorder. In this clinical association study, we attempt to establish the contribution of genetic modifiers by investigating the range of phenotypes encountered in a cohort of 32 patients with genotype L444P/ L444P.

\section{METHODS \\ Subjects}

The clinical records of 70 patients with Gaucher disease with nervous system involvement were reviewed. The majority of these patients were examined at the NIH Clinical Center and provided informed consent under IRB-approved clinical protocols. In several cases, including the three Norrbottnian patients, clinical records, cell lines, and DNA were provided by clinical collaborators.

\section{Mutation analysis}

High molecular weight DNA was isolated from blood, EBVtransformed lymphoblasts, or fibroblast cell lines from the patients. In most cases, DNA was initially screened for the common mutations N370S, L444P, R463C, c.84-85insG, IVS2+l G $\rightarrow$ A, and 55 bp deletion (c.1263-1317del). To better characterise the L444P alleles, all exonic and flanking intronic regions were selectively amplified in three fragments ranging from 1.7 to $3 \mathrm{~kb}$ in length. All mutations were confirmed by direct sequencing and special attention was paid to the sequence of introns and exons in the downstream

Abbreviations: BAER, brain stem auditory evoked response; ERT, enzyme replacement therapy; GBA, glucocerebrosidase; SSEP, somatosensory evoked potential; WISC, Wechsler Intelligence Scale 
regions of GBA to confirm the absence of pseudogene sequence. ${ }^{13}$

\section{Southern blot analyses}

Southern blots were performed to exclude the presence of a recombinant allele resulting from reciprocal crossover. Briefly, genomic DNA was digested with the restriction enzymes SstII, SspI, or HincII, electrophoresed on a $0.6 \%$ I.D.N.A. agarose gel, transferred to nitrocellulose, and hybridised with a ${ }^{32}$ P-labeled GBA cDNA probe. ${ }^{13}$

\section{Enzyme assay}

Glucocerebrosidase activity was measured in fibroblast and/ or EBV-transformed lymphoblast cell pellets using the 4methylumbelliferyl- $\beta$-D glucopyranoside substrate, as previously described.$^{14}$ The enzymatic assays were all performed in a single laboratory.

\section{RESULTS}

Direct sequencing and Southern blots identified a total of 32 children (15M:17F) homozygous for point mutation L444P, including two siblings (cases 14 and 15). None had a recombinant or a fusion allele.

Table 1 summarises the demographics and clinical course in this cohort. Among the 32 L444P homozygotes, there was a wide range of geographical and ethnic backgrounds, including three from the Norrbottnian region of Sweden, ten of Hispanic origin, two African-Americans, and one with Hispanic and Iranian heritage. Consanguinity was recorded in one family (case 9). The age at diagnosis ranged from 2 months to 2.5 years, with a mean of 15 months. The clinical course and outcome observed in these patients varied from young children with severe systemic and/or nervous system involvement that led to early death, to relatively asymptomatic college students, as illustrated by four cases in fig 1 . Nine of the 32 underwent splenectomy, and of these, seven patients were splenectomised before enzyme replacement therapy (ERT) was available. Most splenectomised patients had a fulminant clinical course, including three who developed pulmonary hypertension or cirrhosis with oesophageal varices, and died by adolescence. One patient died following bone marrow transplantation. The overall mortality among the 27 subjects with available follow-up data was $15 \%$. In contrast, $25 \%(8 / 32)$ had only minimal neurologic involvement and normal cognition, although their systemic manifestations varied.

The neurologic features are detailed in table 2 . The common finding reported in each patient was slowed horizontal saccadic eye movements. In some, the eye movement abnormality was described as mild, and in the others the finding was not documented at the time of diagnosis. However, on subsequent neurophthalmologic evaluations, the saccadic abnormality was ultimately detected, in some cases (11 and 27) several years after the initial diagnosis. Although EEG abnormalities, especially slowed background activity, were commonly encountered (18/32), clinical seizures were rare and occurred in approximately $16 \%$ (5/32). Usually the onset of seizures was within a few years after the clinical diagnosis of Gaucher disease, although one patient (case 30) developed clinical seizures significantly later, at age 18. Other EEG findings included a diffuse encephalopathic pattern and generalised epileptiform activity. The brain stem auditory evoked response (BAER) was abnormal in eight (8/ 19) and somatosensory evoked potential (SSEP) abnormalities were present in three (3/18). Other neurological symptoms included ataxia in two patients and myoclonus in one. Brain stem involvement, verified clinically by progressive swallowing dysfunction, was noted in one patient. Dementia and progressive spasticity were seen only in the Norrbottnian isolate.

Data regarding developmental outcome were available for 23 cases, and varied from normal cognition to developmental delay of varying degrees. A formal neuropsychological evaluation was performed in 21 . Of 19 patients tested using the Wechsler Intelligence Scale (WISC), eight had normal $(\mathrm{IQ} / \mathrm{DQ} \geqslant 81$ ), two had borderline (IQ/DQ 70-80), and nine had below average $(\mathrm{IQ} / \mathrm{DQ} \leqslant 69)$ intellectual skills. The most common problem was speech delay, seen in 12 cases, with or without other developmental problems (12/23), although six had only mild expressive delays. Two boys with moderatesevere mental retardation were diagnosed with autism and one female patient with developmental delay exhibited autistic features.

The residual enzyme activity (fig 2) ranged from less than $1 \%$ to $13.3 \%$ of control values. Five cases had severe manifestations despite higher enzyme activity. Patients 2, 3, and 5 had the most severe systemic involvement and two died by adolescence. Patient 22 had relatively mild systemic disease, but suffered from generalised seizures and ataxia, and patient 29 presented with brain stem involvement. In contrast, the two patients (11 and 17) with the lowest residual enzyme levels had the mildest phenotypes and normal cognition, and exhibited only the eye movement abnormality.

Before ERT was available, two patients underwent bone marrow transplantation and one died soon after the transplant due to sepsis. The second patient, transplanted at age 2, continued to have cognitive delays with persistent organomegaly, and was started on ERT at age 9. Enzyme replacement, usually administered at a dose of $60 \mathrm{IU} / \mathrm{kg}$ every other week, reversed many of the systemic manifestations in all 23 patients on therapy. The youngest patient to receive treatment was 4 months and the oldest started at age 20. Six patients received high-dose therapy $(\geqslant 120 \mathrm{IU} / \mathrm{kg})$.

\section{DISCUSSION}

It is becoming increasingly clear that Mendelian diseases are not "simple". Patients with single-gene traits have complicated phenotypes that are affected by the environment, by different thresholds of protein expression, ${ }^{15}{ }^{16}$ or by the genotype at other loci, referred to as modifier genes. ${ }^{17} \mathrm{~A}$ modifying locus for a Mendelian trait is defined as an inherited genetic variation leading to a qualitative or quantitative difference in any aspect of the disease phenotype. Many genetic disorders such as cystic fibrosis ${ }^{18}$ and familial adenomatous polyposis ${ }^{19} 20$ are influenced by modifier loci distinct from the disease locus.

Although the effects of genetic modifiers have only recently gained recognition as an explanation for the variability of phenotypes in humans, evidence of modifying effects has been well established in mice. A range of phenotypes, not explained by disease-causing alleles or environmental factors, is often encountered among inbred strain backgrounds. For example, the mouse model of Mininduced intestinal neoplasia ${ }^{21}$ shows diverse phenotypes, similar to the genetic heterogeneity observed in familial adenomatous polyposis. Mom-l was identified as a major modifier locus causing the phenotypic variation. ${ }^{22}$ Unfortunately, there is not an appropriate mouse model of Gaucher disease to study the phenotypic differences for a given disease-causing GBA mutation. The first mouse model, generated with a null allele, resulted in a neonatal lethal phenotype $^{23}$ and in a second, adult mice carrying the point mutation L444P exhibited partial enzyme deficiency and some systemic inflammation, but lacked Gaucher cells and the phenotypic features of neuronopathic Gaucher disease. ${ }^{24}$ 

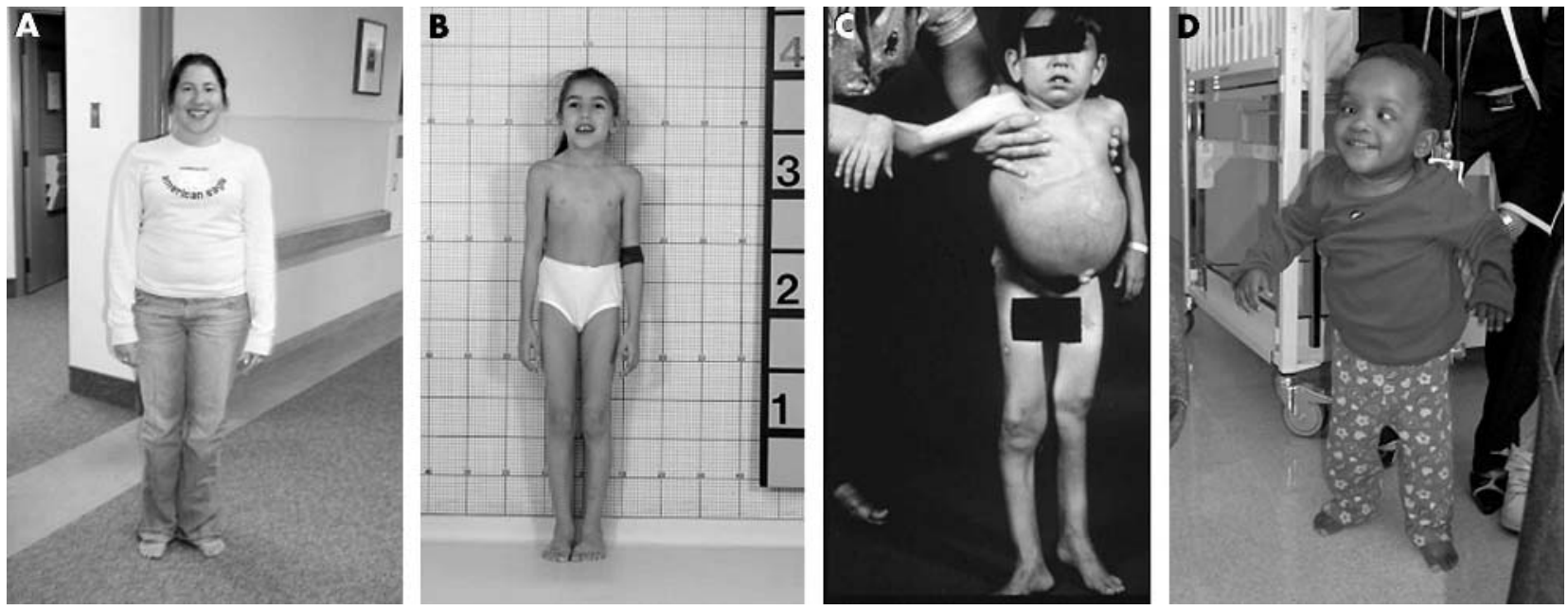

Figure 1 Phenotypic spectrum in patients with genotype L444P/L444P. Among L444P homozygotes, the spectrum of symptoms and disease progression observed ranged from mildly symptomatic young adults exhibiting slowed saccades to young children with brain stem involvement. (A) Patient 16 at age 18. She was diagnosed at age 15 months with organomegaly and horizontal supranuclear palsy. She had skeletal complications before ERT was started at age 7. She is currently a college student and a ballet dancer. (B) Patient 9 at age 8 . She presented with organomegaly and failure to thrive at age 9 months, and ERT was begun at age 1 year. Her current findings include interstitial pulmonary infiltrates and mild learning difficulties, but no skeletal involvement. (C) Patient 3 presented at age 1 year with liver fibrosis, severe bone disease, and portal hypertension. At age 10, he underwent a bone marrow transplant, and died of sepsis shortly afterwards. (D) Patient 29 was diagnosed at age 15 months with organomegaly, ocular apraxia, horizontal supranuclear palsy, and developmental delay. Although ERT was started immediately, at age 26 months she has brain stem involvement with swallowing dysfunction and recurrent stridor. Consents to publish these photographs were provided by the patients and/or parents. The photograph of case 3 was previously published, ${ }^{44}$ and permission for reproduction was granted by both author and publisher.

Mouse models of other disorders have demonstrated that genetic modifiers affect penetrance, and cause variable expressivity or pleiotropy that may alter the phenotype. If Gaucher disease is a fully penetrant Mendelian disorder, modifiers could act both through expressivity and pleiotropy. Expressivity refers to the severity of expression of the phenotype caused by a particular genotype. ${ }^{25}$ Previous genotype-phenotype studies ${ }^{26-28}$ have led to certain generalisations, such as the association of the homozygosity for L444P with neuronopathic Gaucher disease. While in this cohort all patients had neurologic involvement, neither the extent nor the severity of neurologic manifestations could be predicted from the genotype. Previously, it was demonstrated that the majority of presumed L444P homozygotes with type 2 Gaucher disease actually carried at least one recombinant allele. ${ }^{29}$ However, in this series, there was an exception to this observation. One L444P homozygote (case 29) presented with rapidly progressive neurologic disease in early childhood, demonstrating that the genotype is not the only determinant of disease severity. There are other examples demonstrating the lack of uniformity of clinical manifestations in this cohort. Although the eye movement abnormality was the single neurologic finding shared among all the patients, the age when this symptom was detected was highly variable, sometimes not being reported until late childhood. It is recommended that any patient identified with genotype L444P/L444P yet lacking slowed horizontal saccades, be monitored by careful periodic neurophthalmologic examinations before being considered as type 1. Other natural history studies of patients with Gaucher disease have made use of a clinical scoring system to compare disease severity. ${ }^{30}$ Since this scoring system does not take into consideration the patient age, neurologic involvement, or whether treatment was administered, we did not find it useful in this series.

The diverse phenotypic effects of a single gene change, such as the involvement of specific organ systems or the presentation of a given symptom, are referred to as pleiotropy.${ }^{25}$ Genetic modifiers of pleiotropy result in different traits on similar backgrounds. For most pleiotropic disorders, the connection between diverse manifestations is not well understood. Although other genetic mechanisms such as promoter mutations, environment, and other non-genetic causes may play a role, the great variation in systemic involvement in this group of L444P homozygotes suggests the influence of modifier loci. Among the 32 patients, only 50\% had involvement of the skeletal system, liver disease was seen in less than $20 \%$, and there were differing degrees of pulmonary involvement. Pulmonary hypertension, previously suggested as a frequent complication in patients with genotype $\mathrm{L} 444 \mathrm{P} / \mathrm{L} 444 \mathrm{P},{ }^{31}$ was only observed in two cases (4 and 5).

The effect of modifiers can also be demonstrated when the extent to which a trait is evident varies among different genetic backgrounds. In this series, there appear to be differences in the clinical course and outcomes between different ethnic groups. For example, the African-American patients had severe neurologic involvement, while those of Hispanic origin had a less favourable developmental outcome. The three patients from the Norrbottnian genetic isolate in Sweden demonstrated a unique phenotype, characterised by dementia and spasticity.

Various combinations of partially active or null-GBA alleles could lead to variable levels or thresholds of GBA activity and, hence, differing phenotypes. ${ }^{32}$ A threshold model that relates the mutant protein function to a phenotype has been proposed for Mendelian disorders, where a severe phenotype would be observed when the activity of mutant protein/ enzyme is below a certain level and, above that level, the phenotype would be expected to be milder. ${ }^{33}$ While this hypothesis might be valid for certain Gaucher mutations, such as N370S, it does not seem to hold for the L444P allele. In this series of patients with genotype L444P/L444P, the residual enzyme activity was highly variable and did not correlate with disease severity. The degree of the systemic and/or neurologic manifestations could not be predicted from the level of residual enzyme activity, and, in fact, brain stem 
Table 1 Overview of clinical characteristics of 32 patients with Gaucher disease and genotype L444P/L444P

\begin{tabular}{|c|c|c|c|c|c|c|c|c|c|c|c|}
\hline Case & Sex & $\begin{array}{l}\text { Ethnic } \\
\text { background }\end{array}$ & $\begin{array}{l}\text { Age at } \\
\text { diagnosis } \\
\text { (months) }\end{array}$ & $\begin{array}{l}\text { Age at last } \\
\text { follow-up } \\
\text { (years) }\end{array}$ & $\begin{array}{l}\text { Bone } \\
\text { disease }\end{array}$ & $\begin{array}{l}\text { Lung } \\
\text { disease }\end{array}$ & $\begin{array}{l}\text { Other } \\
\text { systems }\end{array}$ & $\begin{array}{l}\text { Splene- } \\
\text { ctomy } \\
\text { (years) }\end{array}$ & Treatment & $\begin{array}{l}\text { Enzyme } \\
\text { therapy* }\end{array}$ & Outcome \\
\hline 1 & M & North Am. & 3 & 12 & Severe & ILD & Cirrhosis & 4 & NA & None & Died at age 12 \\
\hline 2 & $\mathrm{~F}$ & North Am. & 24 & 14 & Moderate & None & $\mathrm{FTT}$ & 2 & NA & None & NA \\
\hline 3 & $M$ & $\begin{array}{l}\text { Dutch- } \\
\text { English }\end{array}$ & 12 & 12 & Severe & None & $\begin{array}{l}\text { Hepatic } \\
\text { fibrosis }\end{array}$ & 3 & BMT & None & $\begin{array}{l}\text { Died at age } 12 \\
\text { after BMT }\end{array}$ \\
\hline 4 & M & North Am. & 7 & 18 & Severe & $\mathrm{PH}$ & $\begin{array}{l}\text { Cirrhosis, } \\
\text { varices }\end{array}$ & 11 & NA & None & Died at age 18 \\
\hline 5 & M & North Am. & 11 & 7 & Severe & $\mathrm{PH}, \mathrm{ILD}$ & $\begin{array}{l}\text { Portal } \\
\text { hyper- } \\
\text { tension }\end{array}$ & 7 & NA & None & $\begin{array}{l}\text { Died at age } 18 \\
\text { due to bleeding } \\
\text { varices }\end{array}$ \\
\hline 6 & $\mathrm{~F}$ & Australian & 12 & 24 & Severe & $\begin{array}{l}\text { Fibrosis, } \\
\text { hypoxia }\end{array}$ & None & None & ERT & $\begin{array}{l}60 \mathrm{lU} / \mathrm{kg}, \\
20 \text { months }\end{array}$ & $\begin{array}{l}\text { Speech delay, } \\
\text { special education }\end{array}$ \\
\hline 7 & $\mathrm{~F}$ & Hispanic & 15 & 18 months & None & None & $\mathrm{FTT}$ & NA & NA & NA & Motor delay \\
\hline 8 & $\mathrm{~F}$ & Hispanic & 12 & 6 & None & None & $\mathrm{FTT}$ & None & ERT & NA & NA \\
\hline 9 & $\mathrm{~F}$ & Spanish & 18 & 9 & None & ILD & None & None & ERT & $\begin{array}{l}60 \mathrm{lU} / \mathrm{kg} \\
20 \text { months }\end{array}$ & Learning problems \\
\hline 10 & $\mathrm{~F}$ & North Am. & 19 & 3 & None & ILD & None & None & ERT & $\begin{array}{l}120 \mathrm{IU} / \mathrm{kg} \\
20 \text { months }\end{array}$ & Normal \\
\hline 11 & $\mathrm{~F}$ & North Am. & 6 & 10 & None & None & None & None & ERT & $\begin{array}{l}120 \mathrm{IU} / \mathrm{kg} \text {, } \\
2 \text { years }\end{array}$ & Normal \\
\hline 12 & M & $\begin{array}{l}\text { African } \\
\text { Am. }\end{array}$ & 12 & 12 & Moderate & None & None & 8 & $\begin{array}{l}\text { Refractory } \\
\text { to ERT }\end{array}$ & $\begin{array}{l}120 \mathrm{IU} / \mathrm{kg} \text {, } \\
15 \text { months }\end{array}$ & $\begin{array}{l}\text { Dev. delay, } \\
\text { speech delay }\end{array}$ \\
\hline 13 & $\mathrm{~F}$ & North Am. & 24 & 17 & None & ILD & None & None & ERT & $\begin{array}{l}60 \mathrm{IU} / \mathrm{kg} \\
3 \text { years }\end{array}$ & Normal \\
\hline 14 & M & Hispanic & 6 & 9 & None & None & None & None & ERT & $\begin{array}{l}60 \mathrm{lU} / \mathrm{kg} \text {, } \\
7 \text { months }\end{array}$ & $\begin{array}{l}\text { Dev. delay, } \\
\text { speech delay, } \\
\text { special education }\end{array}$ \\
\hline 15 & $\mathrm{~F}$ & Hispanic & 2 & 8 & None & None & None & None & ERT & $\begin{array}{l}60 \mathrm{IU} / \mathrm{kg}, \\
4 \text { months }\end{array}$ & Autism \\
\hline 16 & $\mathrm{~F}$ & North Am. & 15 & 21 & $\begin{array}{l}\text { Mild- } \\
\text { moderate }\end{array}$ & $\begin{array}{l}\text { ILD, } \\
\text { clubbing }\end{array}$ & None & None & ERT & $\begin{array}{l}60 \mathrm{IU} / \mathrm{kg} \\
8 \text { years }\end{array}$ & Normal \\
\hline 17 & M & $\begin{array}{l}\text { Irish- } \\
\text { English }\end{array}$ & 15 & 6 & None & None & None & None & ERT & $\begin{array}{l}120 \mathrm{IU} / \mathrm{kg} \\
2 \text { years }\end{array}$ & Normal \\
\hline 18 & $\mathrm{~F}$ & Swedish $†$ & NA & NA & Mild & None & None & None & NA & None & NA \\
\hline 19 & $\mathrm{~F}$ & Swedish† & NA & NA & Severe & None & None & None & NA & None & NA \\
\hline 20 & $M$ & Swedish† & NA & NA & Mild & None & None & None & NA & None & NA \\
\hline 21 & M & North Am. & 16 & 21 & Moderate & None & None & 2 & $\begin{array}{l}\text { BMT, } \\
\text { then ERT }\end{array}$ & $\begin{array}{l}60 \mathrm{lU} / \mathrm{kg}, \\
9 \text { years }\end{array}$ & $\begin{array}{l}\text { Dev. delay, } \\
\text { special education, } \\
\text { bone problems, } \\
\text { stable post-ERT }\end{array}$ \\
\hline 22 & M & Hispanic & 12 & 9 & None & ILD & None & None & ERT & $\begin{array}{l}60 \mathrm{IU} / \mathrm{kg}, \\
14 \text { months }\end{array}$ & $\begin{array}{l}\text { Motor and } \\
\text { speech delay }\end{array}$ \\
\hline 23 & $\mathrm{~F}$ & Hispanic & 18 & 11 & Moderate & $\begin{array}{l}\text { Restrictive } \\
\text { lung } \\
\text { disease } \\
\text { due to } \\
\text { chest } \\
\text { deformity }\end{array}$ & $\begin{array}{l}\text { Cirrhosis, } \\
\text { cardio- } \\
\text { megaly, } \\
\text { reno- } \\
\text { megaly }\end{array}$ & 2 & ERT & $\begin{array}{l}60 \mathrm{IU} / \mathrm{kg} \\
2 \text { years }\end{array}$ & $\begin{array}{l}\text { Learning } \\
\text { problems }\end{array}$ \\
\hline 24 & $\mathrm{~F}$ & Hispanic & 12 & 17 & Mild & ILD & None & None & ERT & $\begin{array}{l}60 \mathrm{IU} / \mathrm{kg}, \\
18 \mathrm{months}\end{array}$ & $\begin{array}{l}\text { Dev. delay, } \\
\text { speech delay }\end{array}$ \\
\hline 25 & $\mathrm{~F}$ & Hispanic & 6 & 9 & None & ILD & $\begin{array}{l}\text { Renal } \\
\text { abnormal- } \\
\text { ities }\end{array}$ & None & ERT & $\begin{array}{l}120 \mathrm{IU} / \mathrm{kg}, \\
12 \text { months }\end{array}$ & $\begin{array}{l}\text { Dev. delay, } \\
\text { speech delay, } \\
\text { autistic tendencies, } \\
\text { special education }\end{array}$ \\
\hline 26 & M & English & 30 & 16 & None & None & None & None & ERT & $\begin{array}{l}60 \mathrm{IU} / \mathrm{kg} \\
3 \text { years }\end{array}$ & Normal \\
\hline 27 & M & North Am. & 22 & 8 & None & ILD & None & None & ERT & $\begin{array}{l}60 \mathrm{IU} / \mathrm{kg} \\
\text { until age } 4, \\
\text { then } 120 \mathrm{IU} / \mathrm{kg}\end{array}$ & Normal \\
\hline 28 & M & Hispanic & 6 & 4 & Mild & ILD & None & None & ERT & $\begin{array}{l}60 \mathrm{IU} / \mathrm{kg} \text {, } \\
7 \text { months }\end{array}$ & $\begin{array}{l}\text { Motor and } \\
\text { speech delay }\end{array}$ \\
\hline 29 & $\mathrm{~F}$ & $\begin{array}{l}\text { African } \\
\text { Am. }\end{array}$ & 4 & 3 & None & $\begin{array}{l}\text { Recurrent } \\
\text { aspiration } \\
\text { pneumonia }\end{array}$ & None & None & ERT & $\begin{array}{l}120 \mathrm{IU} / \mathrm{kg} \\
6 \text { months }\end{array}$ & $\begin{array}{l}\text { Dev. delay, } \\
\text { speech delay, } \\
\text { seizure disorder }\end{array}$ \\
\hline 30 & $\mathrm{~F}$ & Hispanic & 24 & 18 & $\begin{array}{l}\text { Mild- } \\
\text { moderate }\end{array}$ & None & None & 2.5 & ERT & $\begin{array}{l}60 \mathrm{IU} / \mathrm{kg}, \\
3 \text { years }\end{array}$ & $\begin{array}{l}\text { Dev. delay, } \\
\text { speech delay, } \\
\text { special education }\end{array}$ \\
\hline 31 & $M$ & North Am. & 24 & 21 & Moderate & ILD & None & None & ERT & $\begin{array}{l}60 \mathrm{IU} / \mathrm{kg}, \\
2.5 \text { years }\end{array}$ & $\begin{array}{l}\text { Dev. delay, } \\
\text { speech delay }\end{array}$ \\
\hline 32 & M & $\begin{array}{l}\text { Iranian- } \\
\text { Hispanic }\end{array}$ & 30 & 12 & Mild & None & None & None & ERT & $\begin{array}{l}60 \mathrm{lU} / \mathrm{kg}, \\
3 \text { years }\end{array}$ & Autism \\
\hline
\end{tabular}

*Dose and age treatment begun; †Norrbottnian.

Bone disease classifications: Mild, radiologic abnormalities and/or occasional mild pain; Moderate, fractures (including avascular necrosis) and/or chronic pain; Severe, surgery and/or disability due to pain.

Am., American; BMT, bone marrow transplant; Dev., Developmental; ERT, enzyme replacement therapy; FTT, failure to thrive; ILD, interstitial lung disease; NA, not available; PH, pulmonary hypertension. 
Table 2 Neurological features of 32 patients with Gaucher disease and genotype L444P/L444P

\begin{tabular}{|c|c|c|c|c|c|c|c|}
\hline Case & Eye movements & SSEP/VEP & BAER & Seizures & EEG & $\begin{array}{l}\text { Neuropsychological } \\
\text { assessment }^{\star}\end{array}$ & Other findings \\
\hline 1 & HSNP & NA & NA & No & Epileptiform activity & NA & No \\
\hline 2 & HSNP & NA & NA & No & $\begin{array}{l}\text { Increased photic } \\
\text { response }\end{array}$ & NA & No \\
\hline 3 & HSNP & NA & NA & No & $\begin{array}{l}\text { Increased photic } \\
\text { response }\end{array}$ & NA & No \\
\hline 4 & HSNP & NA & Abnormal & $\begin{array}{l}\text { Generalised } \\
\text { seizures }\end{array}$ & Epileptiform activity & NA & No \\
\hline 5 & HSNP & NA & NA & No & DBS & NA & No \\
\hline 6 & $\begin{array}{l}\text { HSNP, vertical } \\
\text { gaze palsy }\end{array}$ & NA & NA & $\begin{array}{l}\text { Generalised } \\
\text { seizures }\end{array}$ & Epileptiform activity & NA & Ataxia, myoclonus \\
\hline 7 & NA & NA & NA & No & NA & NA & No \\
\hline 8 & NA & NA & NA & No & NA & NA & No \\
\hline 9 & HSNP & Abnormal & Normal & No & DBS & Normal & No \\
\hline 10 & HSNP & Normal & Normal & No & Normal & Normal & No \\
\hline 11 & HSNP & Abnormal & Normal & No & Normal & Normal & No \\
\hline 12 & $\begin{array}{l}\text { HSNP, } \\
\text { nystagmus }\end{array}$ & Abnormal & Abnormal & No & Epileptiform activity & Mild & No \\
\hline 13 & HSNP & Normal & Abnormal & No & Normal & Normal & No \\
\hline 14 & HSNP & NA & NA & No & Normal & Mild & No \\
\hline 15 & HSNP & NA & NA & No & DBS & Severe, unable to test & No \\
\hline 16 & HSNP & Normal & Normal & No & DBS & Normal & No \\
\hline 17 & HSNP & Normal & Normal & No & $\begin{array}{l}\text { DBS, increased } \\
\text { photic response }\end{array}$ & Normal & No \\
\hline 18 & NA & NA & NA & No & Normal & NA & No \\
\hline 19 & NA & NA & NA & No & Normal & NA & $\begin{array}{l}\text { Dementia, ataxia, } \\
\text { spasticity }\end{array}$ \\
\hline 20 & NA & NA & NA & No & Normal & NA & $\begin{array}{l}\text { Dementia, ataxia, } \\
\text { spasticity }\end{array}$ \\
\hline 21 & HSNP & Normal & Abnormal & No & DBS & Mild & No \\
\hline 22 & HSNP & Normal & Abnormal & $\begin{array}{l}\text { Generalised } \\
\text { seizures }\end{array}$ & DBS & Normal† & Ataxia \\
\hline 23 & HSNP & NA & NA & NA & DBS & Borderline & No \\
\hline 24 & HSNP & Normal & Normal & No & DBS & Mild & No \\
\hline 25 & HSNP & Normal & Abnormal & No & DBS & Moderate & Clonus \\
\hline 26 & HSNP & Normal & Normal & No & DBS & Normal & No \\
\hline 27 & HSNP & Normal & Normal & No & Normal & Normal & No \\
\hline 28 & HSNP & Normal & Abnormal & No & Normal & Borderline & No \\
\hline 29 & HSNP & Normal & Normal & $\begin{array}{l}\text { Generalised } \\
\text { seizures }\end{array}$ & Epileptiform activity & Severe $†$ & Bulbar signs \\
\hline 30 & HSNP & Normal & Abnormal & $\begin{array}{l}\text { Generalised } \\
\text { seizures } \\
\text { (onset age 18) }\end{array}$ & DBS & Mild & No \\
\hline 31 & HSNP & Normal & Normal & No & NA & Mild & No \\
\hline 32 & HSNP & Normal & Abnormal & $\begin{array}{l}\text { Petit-mal } \\
\text { seizures } \\
\text { (onset age 6) }\end{array}$ & $\begin{array}{l}\text { DBS, spike-wave } \\
\text { activity }\end{array}$ & Moderate & Myoclonus \\
\hline
\end{tabular}

involvement was observed in one case with relatively high enzyme levels (case 29). Both severe and relatively mild phenotypes were seen for a given enzyme activity as well. It should be noted, however, that enzymatic activity was measured in cultured fibroblasts and EBV-transformed lymphoblast cell lines using a synthetic substrate, and may not be an actual reflection of activity in specific tissues, especially the brain.

In addition to modifier loci, environmental factors can alter the severity of phenotype in affected individuals. Exposure to specific stressors, such as viral or other febrile illnesses and surgical interventions, are all non-genetic factors that might impact upon disease progression. Moreover, any intervention applied during the course of the pathologic process can be regarded as an environmental variable, as exemplified by dietary management in disorders of amino acid metabolism. In this cohort, two modalities, splenectomy and ERT, were shown to affect the course in Gaucher disease. Prior to enzyme replacement, splenectomy was commonly performed and usually improved the haematological manifestations. However, two splenectomised patients in our series (cases 2 and 5) had severe systemic involvement without any correlation with the residual enzyme activity. It is still unclear whether splenectomy was a precipitating factor, or whether patients having severe disease required splenectomy. In general, patients with the genotype L444P/L444P clearly have benefited from ERT, with significant improvements in morbidity and mortality. Since ERT does not halt the progression of neurologic manifestations, ${ }^{34}$ the most common clinical finding now associated with genotype L444P/L444P is an isolated horizontal supranuclear palsy. Furthermore, due to the reduction of systemic complications and early mortality with ERT, there is increasing evidence that cognitive and speech deficits are associated with neuronopathic Gaucher disease. In this group, while developmental deficits were documented in the majority, less than 35\% received adequate educational services and support. Current management of patients with Gaucher disease should include screening for and treatment of developmental and language problems.

Modifying genes might influence the phenotype by their specific action on disease pathways or protein-protein 


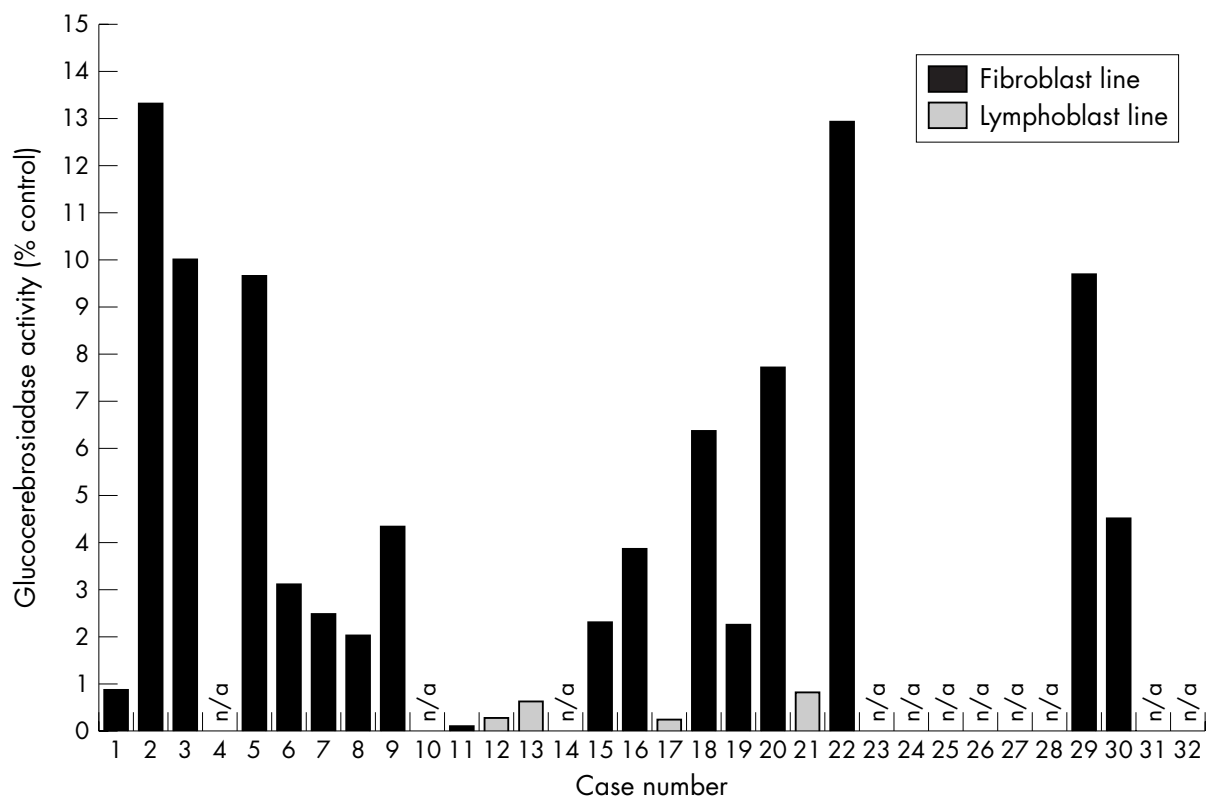

Figure 2 Residual glucocerebrosidase activity in patients with Gaucher disease and genotype L444P/L444P. The residual enzyme activity measured in fibroblasts (solid bars) and lymphoblasts (shaded bars) ranged from less than $1 \%$ to $13.3 \%$ of control values and did not correlate with disease severity. Of note, the lowest enzyme activity was detected in lymphoblasts, which might not reflect glucocerebrosidase activity in brain or other organs.

interactions at the cellular level. Loci effecting chaperone binding, protein folding, and intracellular trafficking have been implicated in other Mendelian disorders..$^{35}{ }^{36}$ In Gaucher disease, modifiers could interfere with intracellular processing of the mutant enzyme, or the turnover of glucocerebroside and/or the toxic intermediate glucosylsphingosine. ${ }^{37}$ Additive effects of distant loci regulating immune response and/or activation of macrophages also could lead to phenotypes discordant with the residual enzyme activity.

The identification of specific genetic modifiers in rare disorders like Gaucher disease is challenging. Exploring specific candidate genes has had very marginal success. ${ }^{38-40}$ The careful characterisation of cohorts sharing the same genotype may facilitate more global approaches using microarrays, haplotype analyses, and proteomics. The complexity of the associated phenotypes in Gaucher disease, including patients described with parkinsonian manifestations ${ }^{41}{ }^{42}$ is another example of how the boundaries between common complex diseases and simple Mendelian disorders are becoming increasingly blurred. The identification of specific genetic modifiers would not only lead to the development of novel therapeutic strategies but might also provide insights into pathogenic mechanisms shared by both Mendelian and complex disorders.

\section{Authors' affiliations}

O Goker-Alpan, K S Hruska, E Orvisky, B K Stubblefield, E Sidransky, NSB/NIMH and MGB/NGHRI, National Institutes of Health, Bethesda, $M D$, USA

P S Kishnani, Duke University Medical Center, Division of Medical Genetics, Durham, NC, USA

R Schiffmann, DMNB/NINDS, National Institutes of Health, Bethesda, $M D$, USA

Competing interests: Dr PS Kishnani has received research and grant support from Genzyme Corporation for work on some lysosomal storage disorders including Gaucher disease. Dr Kishnani is also a member of the Pompe disease advisory board for Genzyme Corporation.

Consents to publish the photographs shown in figure 1 were provided by the patients and/or parents.
Correspondence to: Dr Ellen Sidransky, Section on Molecular Neurogenetics, NSB/NIMH/NIH, 35 Convent Drive 1A100, Bethesda, MD 20892, USA; sidranse@irp.nimh.nih.gov

Revised version received 11 January 2005

Accepted for publication 12 January 2005

\section{REFERENCES}

1 Goker-Alpan O, Schiffmann R, Park JK, Stubblefield BK, Tayebi N, Sidransky E. Phenotypic continuum in neuronopathic Gaucher disease: an intermediate phenotype between type 2 and type 3. J Pediatr 2003; 143:273-6.

2 Hanna R, McDonald MT, Sullivan JA, Mackey JF, Krishnamurthy V, Kishnani PS. Diagnostic and treatment challenges of neuronopathic Gaucher disease: two cases with an intermediate phenotype. J Inherit Metab Dis 2004; 27:687-90.

3 Patterson MC, Horowitz M, Abel RB, Currie JN, Yu KT, Kaneski C, Higgins JJ, $\mathrm{O}^{\prime}$ Neill RR, Pikus A. Isolated horizontal supranuclear gaze palsy as a marker of severe systemic involvement in Gaucher's disease. Neurology 1993:43:1993-7.

4 Sidransky E, Tsuji S, Stubblefield BK, Currie J, Fitzgibbon EJ, Ginns El. Gaucher patients with oculomotor abnormalities do not have a unique genotype. Clin Genet 1992;41:1-5.

5 Erikson A. Gaucher disease-Norrbottnian type (III). Neuropaediatric and neurobiological aspects of clinical patterns and treatment. Acta Paediatr Scand Suppl 1986;326:1-42.

6 Horowitz M, Wilder S, Horowitz Z, Reiner O, Gelbart T, Beutler E. The human glucocerebrosidase gene and pseudogene: structure and evolution. Genomics 1989;4:87-96.

7 Tsuii S, Choudary PV, Martin BM, Stubblefield BK, Mayor JA, Barranger JA, Ginns El. A mutation in the human glucocerebrosidase gene in neuronopathic Gaucher's disease. N Engl J Med 1987;316:570-5.

8 Tayebi N, Stubblefield BK, Park JK, Orvisky E, Walker JM, LaMarca ME, Sidransky E. Reciprocal and nonreciprocal recombination at the glucocerebrosidase gene region: implications for complexity in Gaucher disease. Am J Hum Genet 2003;72:519-34.

9 Beutler E, Grabowski GA. Gaucher disease. In: Scriver CR, Beaudet AL, Sly WS, Valle D, eds. The metabolic and molecular basis of inherited disease, 8th ed. New York, NY: McGraw-Hill, 2001:3635-68.

10 Charrow J, Andersson H, Kaplan P, Kolodny EH, Mistry P, Pastores G, Rosenbloom BE, Scott CR, Wappner RS, Weinreb NJ, Zimran A. The Gaucher registry: demographics and disease characteristics of 1698 patients with Gaucher disease. Arch Intern Med 2000;160:2835-43.

11 Houlston RS, Tomlinson IP. Modifier genes in humans: strategies for identification. Eur J Hum Genet 1998;6:80-8.

12 Nadeau JH. Modifier genes in mice and humans. Nat Rev Genet 2001;2:165-74. 
13 Tayebi N, Reissner K, Lau EK, Stubblefield BK, Klineburgess AC, Martin BM, Sidransky E. Genotypic heterogeneity and phenotypic variation among patients with type 2 Gaucher's disease. Pediatr Res 1998;43:571-8.

14 Peters SP, Lee RE, Glew RH. A microassay for Gaucher's disease. Clin Chim Acta 1975:60:391-6.

15 Scriver CR, Waters PJ. Monogenic traits are not simple: lessons from phenylketonuria. Trends Genet 1999;15:267-72.

16 Dipple KM, McCabe ER. Phenotypes of patients with "simple" Mendelian disorders are complex traits: thresholds, modifiers and systems dynamics. Am J Hum Genet 2000;66:1729-35.

17 Romeo G, McKusick VA. Phenotypic diversity, allelic series and modifier genes. Nat Genet 1994;7:451-3.

18 Aron Y, Polla BS, Bienvenu T, Dall'Ava J, Dusser D, Hubert D. HLA Class II polymorphism in cystic fibrosis: a possible modifier of pulmonary phenotype. Am J Respir Crit Care Med 1999:159:1464-8.

19 Spirio L, Olschwang S, Groden J, Robertson M, Samowitz W, Joslyn G, Gelbert L, Thliveris A, Carlson M, Otterud B. Alleles of the APC gene: an attenuated form of familial polyposis. Cell 1993;75:951-7.

20 Crabtree MD, Tomlinson IPM, Hodgson SV, Neale K, Phillips RK, Houlston RS Explaining variation in familial adenomatous polyposis: relationship between genotype and phenotype and evidence for modifier genes. Gut 2002;51:420-3.

21 Su LK, Kinzler KW, Vogelstein B, Preisinger AC, Moser AR, Luongo C, Gould KA, Dove WF. Multiple intestinal neoplasia caused by a mutation in the murine homolog of the APC gene. Science 1992;256:668-70.

22 Dietrich WF, Lander ES, Smith JS, Moser AR, Gould KA, Luongo C, Borenstein N, Dove W. Genetic identification of Mom-1, a major modifier locus affecting Min-induced intestinal neoplasia in the mouse. Cell 1993:75:631-9.

23 Tybulewicz VL, Tremblay ML, LaMarca ME, Willemsen R, Stubblefield BK, Winfield S, Zablocka B, Sidransky E, Martin BM, Huang SP, Mintzer KA, Westphal H, Mulligan RC, Ginns El. Animal model of Gaucher's disease from targeted disruption of the mouse glucocerebrosidase gene. Nature 1992;357:407-10.

24 Mizukami H, Mi Y, Wada R, Kono M, Yamashita T, Liu Y, Werth N, Sandhoff R, Sandhoff K, Proia RL. Systemic inflammation in glucocerebrosidase-deficient mice with minimal glucosylceramide storage. J Clin Invest 2002;109:1215-21.

25 Nussbaum RL. Patterns of single-gene inheritance. In: Nussbaum RL, Mclnnes RR, Willard FH, eds. Thompson \& Thompson genetics in medicine, 6th ed. Philadelphia, PA: WB Saunders, 2001:51-78.

26 Grabowski GA. Gaucher disease: gene frequencies and genotype-phenotype correlations. Genet Test 1997;1:5-12.

27 Koprivica V, Stone DL, Park JK, Callahan M, Frisch A, Cohen IJ, Tayebi N, Sidransky E. Analysis and classification of 304 mutant alleles in patients with type 1 and type 3 Gaucher disease. Am J Hum Genet 2000;66:1777-86.

28 Zhao H, Keddache M, Bailey L, Arnold G, Grabowski GA. Gaucher's disease: identification of novel mutant alleles and genotype-phenotype relationships. Clin Genet 2003;64:57-64.
29 Stone DL, Tayebi N, Orvisky E, Stubblefield BK, Madike V, Sidransky E. Glucocerebrosidase gene mutations in patients with type 2 Gaucher disease. Hum Mutat 2000;15:181-8

30 Zimran A, Sorge J, Gross E, Kubitz M, West C, Beutler E. Prediction of severity of Gaucher's disease by identification of mutations at DNA level. Lancet 1989;2:349-52.

31 Santamaria F, Parenti G, Guidi G, Filacamo M, Strisciuglio P, Grillo G, Farina V, Sarnelli P, Rizzolo MG, Rotondo A, Andria G. Pulmonary manifestations of Gaucher disease: an increased risk for L444P homozygotes? Am J Respir Crit Care Med 1998;157:985-9.

32 Grabowski GA, Horowitz M. Gaucher's disease: molecular, genetic and enzymological aspects. Baillieres Clin Haematol 1997;10:635-56.

33 Dipple KM, Phelan JK, McCabe ER. Consequences of complexity within biological networks: robustness and health, or vulnerability and disease. Mol Genet Metab 2001;74:45-50.

34 Altarescu G, Hill S, Wiggs E, Jeffries N, Kreps C, Parker CC, Brady RO, Barton NW, Schiffmann R. The efficacy of enzyme replacement therapy in patients with chronic neuronopathic Gaucher's disease. J Pediatr $2001 ; 138: 539-47$

35 Gamez A, Perez B, Ugarte M, Desviat LR. Expression analysis of phenylketonuria mutations. Effect on folding and stability of the phenylalanine hydroxylase protein. J Biol Chem 2000;275:29737-42.

36 Gregersen N, Bross P, Andrese BS, Pedersen CB, Corydon TJ, Bolund L. The role of chaperone-assisted folding and quality control in inborn errors of metabolism: protein folding disorders. J Inherit Metab Dis 2001 ;24:189-212.

37 Orvisky E, Park JK, LaMarca ME, Ginns El, Martin BM, Tayebi N, Sidransky E. Glucosylsphingosine accumulation in tissues from patients with Gaucher disease: correlation with phenotype and genotype. Mol Genet Metab 2002;76:262-70.

38 Beutler E, West C. Polymorphisms in glucosylceramide (glucocerebroside) synthase and the Gaucher disease phenotype. Isr Med Assoc J 2002;4:986-8

39 Altarescu G, Phillips M, Foldes AJ, Elstein D, Zimran A, Mates M. The interleukin-6 promoter polymorphism in Gaucher disease: a new modifier gene? QJM 2003;96:575-8.

40 Beutler E, Beutler L, West C. Mutations in the gene encoding cytosolic $\beta$ glucosidase in Gaucher disease. J Lab Clin Med 2004;144:65-8.

41 Bembi B, Zambito MS, Sidransky E, Ciana G, Carrozzi M, Zorzon M, Martini C, Gioulis M, Pittis MG, Capus L. Gaucher's disease with Parkinson's disease: clinical and pathological aspects. Neurology 2003;61:99-101.

42 Tayebi N, Walker J, Stubblefield B, Orvisky E, LaMarca ME, Wong K, Rosenbaum H, Schiffmann R, Bembi B, Sidransky E. Gaucher disease with parkinsonian manifestations: does glucocerebrosidase deficiency contribute to a vulnerability to parkinsonism? Mol Genet Metab 2003;79:104-9.

43 AAMR. Mental retardation: definition, classification and systems of supports, 9th ed. Washington, DC: American Association on Mental Retardation, 1992.

44 Rappeport JM, Ginns El. Bone-marrow transplantation in severe Gaucher disease. N Engl J Med 1984;311:84-8. 